\title{
Problématique de recherche sur les systèmes sylvo-pastoraux du Massif-Central
}

\author{
P. Balandier ${ }^{\mathrm{a}}$, C. Dupraz ${ }^{\mathrm{b}}$, H. Rapey ${ }^{\mathrm{a}}$, F.X. de Montard ${ }^{\mathrm{c}}$ \\ "Cemagref, 24, avenue des Landais, BP 50085, 63172 Aubière cedex ; "Inra, LEPSE, \\ 2, place Viala, 34060 Montpellier ; 'Inra agronomie, avenue du Brézet, 63039 Clermont- \\ Ferrand, France
}

Dans les zones sensibles en déprise du Massif Central, une forte avancéc de la forêt par accrus spontanés ou par plantations, résulte souvent de l'abandon de pratiques pastorales ancestrales. Depuis 1989, le Cemagref et l'Inra ont entrepris en Auvergne et en Languedoc-Roussillon la recherche de nouveaux schémas de mise en valcur articulant la production de bois et le maintien de l'activité d'élevage. Ces travaux sont développés à différents niveaux d'approche : i) l'analyse de l'effet de l'introduction d'arbres dans des milieux très ouverts tels que des prairies pâturées, ou au contraire de l'ouverture au pâturage de milieux boisés très fermés ; ii) l'analyse des processus biologiques pour le végétal, des processus techniques et écologiques pour la parcelle et des processus économiques à l'échelle de l'exploitation familiale. Dans l'état actuel des travaux, il ressort que les principales questions pour une agroforesterie durable sont : 1) l'adaptation des essences et l'obtention de cultivars plus ubiquistes ; 2) la meilleure connaissance des mécanismes de réponse à la taille et des interactions cntre l'arbre et l'herbe ; 3) la mise au point d'une méthode d'analyse technico-économique des systèmes sylvopastoraux qui tienne compte à la fois du revenu, du patrimoine et des contraintes de ces systèmes.

\section{Grazing impact on butterflies in coastal dunes}

\section{M.F. WallisDeVries, I. Raemakers}

\section{Dutch Butterfly Conservation, P.O. Box 506, 6700 AM Wageningen, the Netherlands}

Grazing at low stocking rates has become a common management practice in nature reserves in the Netherlands. However, detailed knowledge of grazing impact is often poor, in particular for the entomofauna. This study adressed the impact of extensive grazing on butterflies. Butterflies are critical indicators of habitat quality for many plant and animal species. We compared monitoring data from 1992 to 1996 for 12 grazed, seven ungrazed and four mown calcareous dune areas in the Netherlands. Grazing typically concerned ycarround grazing by cattle and/or horses, at low stocking rates $(0.05-0.27$ head $\left.\cdot h a^{-1}\right)$. Changes in butterfly species abundance were positive in grazed and ungrazed areas compared to mown areas $(P<0.01)$; correlation coefficients of species abundance against time were + $0.13 \pm 0.04,+0.11 \pm 0.05$ and $-0.11 \pm 0.06$ respectively. Species richness was not affected by management (18.6 \pm 3.3 species per area, $P=0.87$ ), but individual species differed in their response. Species from open grassland benefitted most from grazing, particularly $I$ ssoria lathonia and Lycaena phlaeas. Both showed a relative increase in abundance in grazed areas compared to ungrazed and mown areas between 1992 and $1996(P<0.025)$, and were also most abundant in grazed areas in 1996 $(P<0.025)$. Canonical correspondence analysis showed that species occurrence was not always positively related to grazing. However, three endangered species for the Netherlands (Issoria lathonia, Hipparchia semele and Pyrgus malvae') were positively associated with grazing. Extensive grazing therefore can be considered as a valuable management measure in dune areas. However, in the long run very low stocking rates $\left(<0.05 \mathrm{head} \cdot \mathrm{ha}^{-1}\right)$ seem advisable to accomodate species from open habitats as well as tall grasslands and woodland. 